\title{
Gastric Leiomyoma and Hyperplastic Polyposis Coli in a Patient with Multiple Cutaneous and Uterine Leiomyomatosis
}

\author{
David Serra, Pedro Amaro, Margarida Gonçalo, Mário Silva, Barbara Ferrando, Barbara Pasini, and \\ Américo Figueiredo
}

Background: Cutaneous leiomyomatosis has been associated with multiple uterine myomas and, more recently, with germline heterozygous mutations of the $\mathbf{F H}$ gene and certain types of renal cancer. Despite the growing amount of knowledge concerning this genodermatosis, its clinical spectrum remains incompletely characterized.

Objective: We report the observation of a patient with multiple cutaneous and uterine leiomyomatosis (MCUL) with unusual gastrointestinal manifestations.

Methods and Results: A gastric leiomyoma was diagnosed on a 38-year-old female MCUL patient on endoscopy performed because of mild dyspepsia. Furthermore, routine colonoscopy disclosed hyperplastic polyposis. Genetic testing revealed a previously not reported mutation of the $\mathrm{FH}$ gene.

Conclusion: Gastrointestinal lesions such as the present ones are frequently asymptomatic and probably underdiagnosed. As the phenotypical spectrum associated with mutations of the $F H$ gene keeps expanding, clinicians should keep in mind that, besides renal cancer, other unexpected tumors could also arise in this setting.

Renseignements de base: La léiomyomatose cutanée a été associée à des myomes utérins multiples et plus récemment à des mutations germinales hétérozygotes du gène $\mathrm{FH}$ et également à certains types de cancer du rein. Malgré la quantité croissante de connaissances acquises sur cette génodermatose, la caractérisation de son spectre clinique demeure incomplète.

Objectif: Nous signalons l'observation d'une patiente présentant une léiomyomatose cutanée et utérine familiale et des manifestations gastro-intestinales inhabituelles.

Méthodes et résultats: Un léiomyome gastrique a été diagnostiqué chez une femme de 38 ans présentant une léiomyomatose cutanée et utérine familiale à la suite d'une endoscopie réalisée pour cause de dyspepsie d'intensité légère. De plus, une coloscopie de routine a révélé une polypose hyperplasique. Un test génétique a révélé une mutation du gène $F H$ non signalée antérieurement.

Conclusion: Des lésions gastro-intestinales comme celles-ci sont fréquemment asymptomatiques et probablement sousdiagnostiquées. Alors que le spectre phénotypique associé aux mutations du gène $F H$ continue de s'étendre, les cliniciens doivent retenir qu'outre le cancer du rein, d'autres tumeurs inattendues pourraient également, en l'occurrence, se présenter.

\section{$M$ ULTIPLE CUTANEOUS AND UTERINE LEIOMY- OMATOSIS $^{1-3}$ (MCUL; OMIM \#150800) has been} associated with renal cancer, ${ }^{4}$ uterine leiomyosarcomas, ${ }^{4,5}$ and, more recently, macronodular adrenocortical disease, ${ }^{6}$

From the Departments of Dermatology, Gastroenterology and Pathology, Hospitais da Universidade de Coimbra, Coimbra, Portugal, and Department of Genetics, Biology and Biochemistry, University of Turin, Turin, Italy.

Address reprint requests to: David Serra, MD, Hospitais da Universidade de Coimbra, Serviço de Dermatologia, Praceta Prof. Mota Pinto, 3000075 Coimbra, Portugal; e-mail: david.serra.fernandes@gmail.com.

DOI 10.2310/7750.2011.11026

(C) 2012 Canadian Dermatology Association

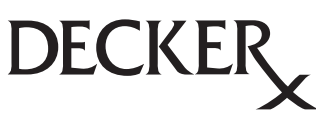

benign ovarian tumors, ${ }^{7}$ and Leydig cell tumors of the testis. ${ }^{8}$ These recent publications support the concept that the clinical spectrum of this syndrome is still expanding. ${ }^{9}$ We report the observation of a MCUL patient with a gastric leiomyoma and colonic polyposis carrying a new mutation of the fumarate hydratase $(F H)$ gene. ${ }^{10}$

\section{Case Report}

A 44-year-old female patient presented with several longstanding, occasionally painful, erythematous papules and nodules in her trunk and upper limbs (Figure 1) that started to appear around age 20. A diagnosis of piloleiomyomas was confirmed on histopathology. 


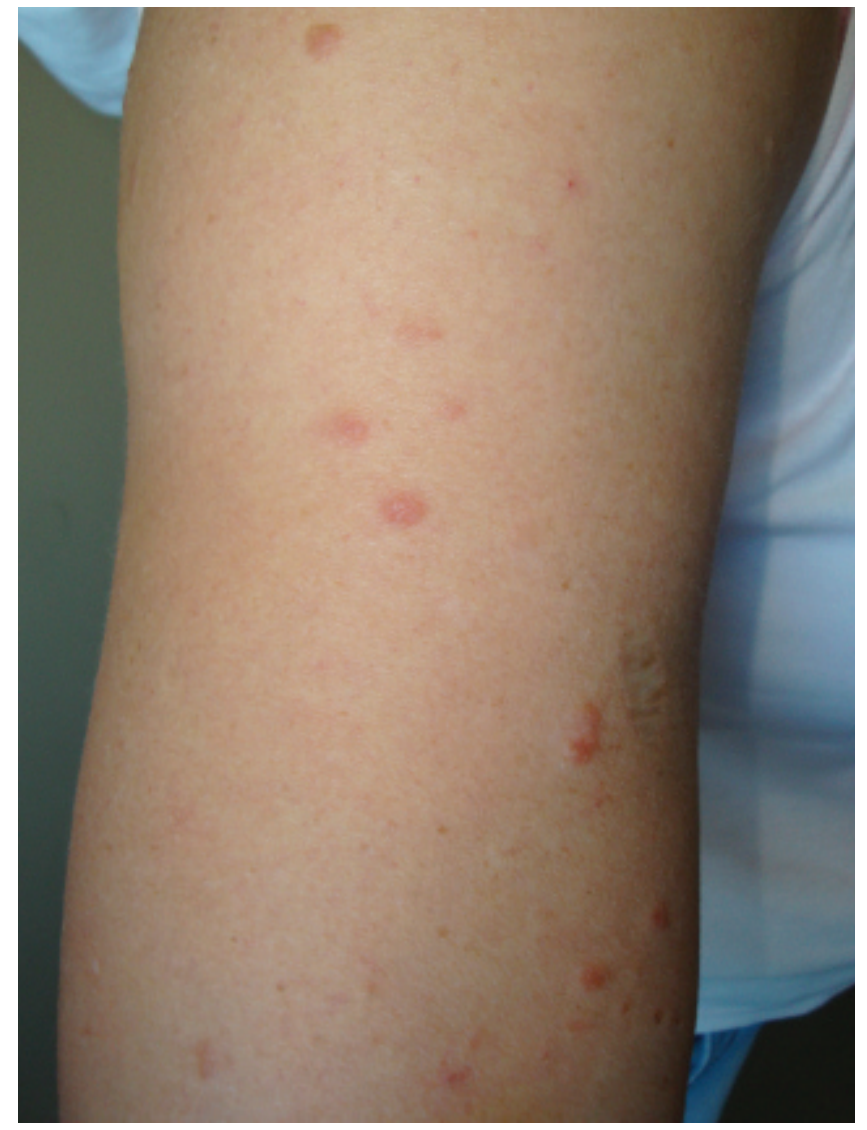

Figure 1. Multiple piloleiomyomas on the right arm.

Her past medical history was significant for several conditions and surgical treatments. Due to dysmenorrhea and bleeding, multiple uterine leiomyomas were diagnosed at age 37, and a hysterectomy was performed thereafter. Later, at age 38, a submucosal tumor of the gastric corpus was diagnosed on esophagogastroduodenoscopy for minor dyspeptic symptoms (Figure 2). Surgical local excision revealed a gastric leiomyoma (actin positive, c-Kit negative). By the age of 39, a colonoscopy showed more than 20 sessile polyps, hyperplastic in multiple biopsies, located mostly on the ascending colon, some featuring a laterally spreading morphology with dimensions ranging from 10 to $30 \mathrm{~mm}$ in diameter. Considering this, the criteria for the diagnosis of hyperplastic polyposis according to the World Health Organization classification, as proposed by Jass and Burt in 2000, were fulfilled. ${ }^{11}$ Given the potential for malignant degeneration and the uncertainties of endoscopic management, the patient decided on a surgical approach (a prophylactic colectomy).

Her family history was not contributory but could not be completely assessed as her father died at a young age, after an accident, and her grandparents' medical history is unknown.

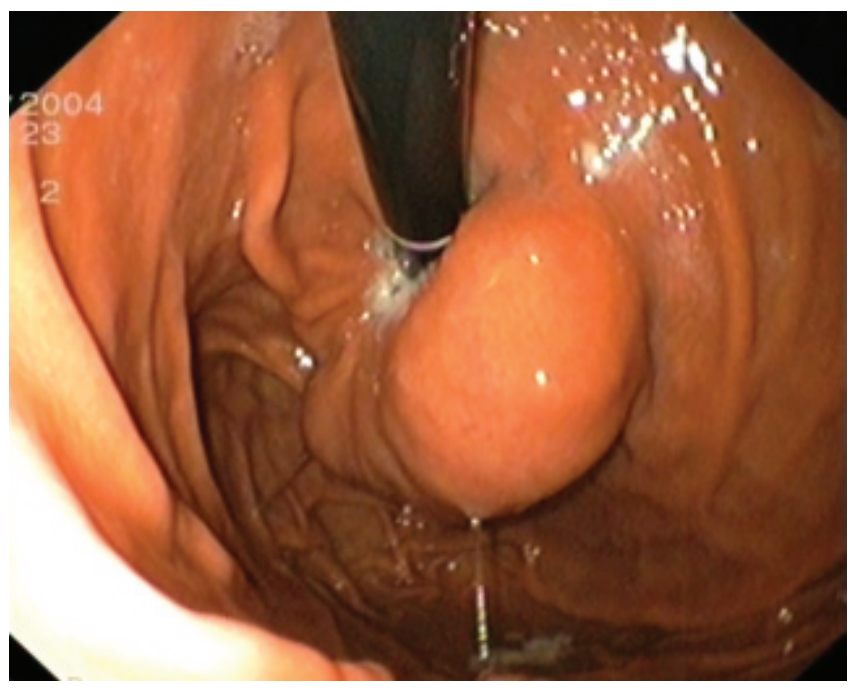

Figure 2. An asymptomatic gastric leiomyoma revealed as a large submucosal tumor $(6.5 \times 2.5 \times 2.5 \mathrm{~cm})$ on endoscopy.

Genetic testing revealed a nonsense mutation in exon 4 of the FH gene (c.422G>A, p.Trp141X). This mutation generates a premature stop codon and has not yet been reported to the Leiden Open Variation Database of FH mutations. ${ }^{12}$

A diagnosis of MCUL associated with a gastric leiomyoma and colonic hyperplastic polyposis was established. Periodic renal and rectal cancer screening has been negative, and the patient remains healthy.

\section{Discussion}

Piloleiomyomas can present as solitary or, more frequently, multiple lesions. In the latter case, they usually represent an autosomal dominant inherited condition associated with uterine myomas: MCUL. ${ }^{10}$ A subset of MCUL families has individuals affected with certain types of aggressive renal cancer, namely, type 2 papillary renal cell carcinomas and collecting duct carcinomas ${ }^{4}$ : hereditary leiomyomatosis and renal cell cancer (HLRCC; OMIM \#605839). Mutations of the FH gene are present in both MCUL and HLRCC patients. ${ }^{10,13}$ As no significant genotype-phenotype correlation has been established, identification of families with renal cancer risk cannot rely on genetic testing.

The FH gene encodes fumarate hydratase, an enzyme of the tricarboxylic acid (Krebs) cycle. Its role as a tumor suppressor gene is now widely accepted. Putative mechanisms through which $\mathrm{FH}$ promotes tumorigenesis include oxygen-independent stabilization of hypoxia-inducible transcription factor and activation of cellular hypoxia response pathways (a pseudohypoxic drive), as well as 
downregulation of serum response factor-regulated transcripts, particularly the FOS-JUNB pathway. ${ }^{14-17}$

In this case, a MCUL patient presented with a gastric leiomyoma and colonic hyperplastic polyposis, two previously unreported pathologic associations to the best of our knowledge. The common smooth muscle origin of gastric, cutaneous, and uterine tumors supports the contention that this is not a casual occurrence, and it is conceivable that the neoplastic predisposition associated with a mutated $F H$ could justify the development of these lesions.

Lamba and colleagues reported the case of a woman with MCUL and a gastrointestinal stromal tumor (GIST) diagnosed by the age of 36 years. ${ }^{18}$ Although GISTs share a mesenchymal origin with leiomyomas, there are several morphologic and biologic aspects suggesting that GISTs derive from a different cell type, namely, the precursors of the interstitial cells of Cajal. ${ }^{19}$

On the other hand, FH mutations have not been associated with hyperplastic polyposis, a rare condition whose malignant potential has been acknowledged since the late $1980 \mathrm{~s}^{20}$ Its genetic basis is still far from understood but has been linked to the serrated neoplastic pathway of colorectal carcinogenesis. ${ }^{21}$ Although this case could merely consist of an association by chance, one might also consider a possible role for $F H$ in colonic polyposis.

The gastrointestinal lesions described in this case are frequently asymptomatic and probably underdiagnosed. As the clinical spectrum associated with cutaneous leiomyomatosis keeps expanding, clinicians following these patients should bear in mind that other unexpected tumors could arise in this setting. Future research should clarify the implications of $F H$ mutations and improve the management of these patients.

\section{Acknowledgment}

Financial disclosure of authors: The work of B.F. and B.P. was supported by Compagnia di San Paolo (Progetto Oncologia), AIRC (Italian Association on Cancer Research), Ricerca Finalizzata Regione Piemonte.

Financial disclosure of reviewers: None reported.

\section{References}

1. Kloepfer HW, Krafchuk J, Derbes V, et al. Hereditary multiple leiomyoma of the skin. Am J Hum Genet 1958;10:48-52.

2. Mezzadra G. Leiomioma cutaneo multiplo ereditario. Studio di un caso sistematizzato in soggetto maschile appartenente a famiglia portatrice di leiomiomatosi cutanea e fibromiomatosi uterina Minerva Derm 1965;40:388-93.

3. Reed WB, Walker R, Horowitz R. Cutaneous leiomyomata with uterine leiomyomata. Acta Derm Venereol 1973;53:409-16.

4. Launonen V, Vierimaa O, Kiuru M, et al. Inherited susceptibility to uterine leiomyomas and renal cell cancer. Proc Nat Acad Sci U S A 2001;98:3387-92, doi:10.1073/pnas.051633798.

5. Ylisaukko-oja SK, Kiuru M, Lehtonen HJ, et al. Analysis of fumarate hydratase mutations in a population-based series of early onset uterine leiomyosarcoma patients. Int J Cancer 2006;119:2837, doi:10.1002/ijc. 21798 .

6. Matyakhina L, Freedman RJ, Bourdeau I, et al. Hereditary leiomyomatosis associated with bilateral, massive, macronodular adrenocortical disease and atypical Cushing syndrome: a clinical and molecular genetic investigation J Clin Endocrinol Metab 2005; 90:3773-9.

7. Ylisaukko-oja SK, Cybulski C, Lehtonen R, et al. Germline fumarate hydratase mutations in patients with ovarian mucinous cystadenoma. Eur J Hum Genet 2006;14:880-3, doi:10.1038/ sj.ejhg.5201630.

8. Carvajal-Carmona LG, Alam NA, Pollard PJ, et al. Adult Leydig cell tumors of the testis caused by germline fumarate hydratase mutations. J Clin Endocrinol Metab 2006;91:3071-5, doi:10.1210/ jc.2006-0183.

9. Lehtonen HJ, Kiuru M, Ylisaukko-Oja SK, et al. Increased risk of cancer in patients with fumarate hydratase germline mutation. J Med Genet 2006;43:523-6, doi:10.1136/jmg.2005.036400.

10. Tomlinson IP, Alam NA, Rowan AJ, et al. Germline mutations in FH predispose to dominantly inherited uterine fibroids, skin leiomyomata and papillary renal cell cancer. Nat Genet 2002;30: 406-10, doi:10.1038/ng849.

11. Jass JR, Burt R. Hyperplastic polyposis. In: Hamilton SR, Aaltonen LA, editors. WHO international classification of tumors: pathology and genetics of tumors of the digestive system. 3rd ed. Berlin: Springer-Verlag; 2000. p. 135-6.

12. Bayley JP, Launonen V, Tomlinson IP. The FH mutation database: an online database of fumarate hydratase mutations involved in the MCUL (HLRCC) tumor syndrome and congenital fumarase deficiency. BMC Med Genet 2008;9:20, doi:10.1186/1471-2350-9-20.

13. Merino MJ, Torres-Cabala C, Pinto $\mathrm{P}$, et al. The morphologic spectrum of kidney tumors in hereditary leiomyomatosis and renal cell carcinoma (HLRCC) syndrome. Am J Surg Pathol 2007;31: 1578-85, doi:10.1097/PAS.0b013e31804375b8.

14. Isaacs JS, Jung YJ, Mole DR, et al. HIF overexpression correlates with biallelic loss of fumarate hydratase in renal cancer: novel role of fumarate in regulation of HIF stability. Cancer Cell 2005;8:14353, doi:10.1016/j.ccr.2005.06.017.

15. Sudarshan S, Sourbier C, Kong HS, et al. Fumarate hydratase deficiency in renal cancer induces glycolytic addiction and hypoxia-inducible transcription factor lalpha stabilization by glucose-dependent generation of reactive oxygen species. Mol Cell Biol 2009;29:4080-90, doi:10.1128/MCB.00483-09.

16. Raimundo N, Ahtinen J, Fumić K, et al. Differential metabolic consequences of fumarate hydratase and respiratory chain defects. Biochim Biophys Acta 2008;1782:287-94.

17. Raimundo N, Vanharanta S, Aaltonen LA, et al. Downregulation of SRF-FOS-JUNB pathway in fumarate hydratase deficiency and in uterine leiomyomas. Oncogene 2009;28:1261-73, doi:10.1038/onc. 2008.472. 
18. Lamba M, Verma S, Prokopetz R, et al. Multiple cutaneous and uterine leiomyomas associated with gastric GIST. J Cutan Med Surg 2005;9:332-5, doi:10.1007/s10227-005-0114-3.

19. Kindblom LG, Remotti HE, Aldenborg F, et al. Gastrointestinal pacemaker cell tumor (GIPACT): gastrointestinal stromal tumors show phenotypic characteristics of the interstitial cells of Cajal. Am J Pathol 1998;152:1259-69.
20. Bengoechea O, Martinez-Penuela JM, Larrinaga B, et al. Hyperplastic polyposis of the colorectum and adenocarcinoma in a 24-year-old man. Am J Surg Pathol 1987;11:323-7, doi:10.1097/ 00000478-198704000-00010.

21. Legett BA, Whitehall V. Role of the serrated pathway in colorectal cancer pathogenesis. Gastroenterology 2010;138:2088-100, doi:10. 1053/j.gastro.2009.12.066. 